\title{
Latvijas lietuviešu sarunvalodas specifika: darbības vārdu lietošana
}

\section{Specificity of the spoken language of Latvian Lithuanians: the use of verbs}

\author{
Regīna Kvašìte \\ Šauļu Universitāte, Sociālo, humanitāro zinātņu un mākslu fakultāte \\ Lietuviešu valodniecības, literatūras un komunikācijas katedra \\ P. Višinskio g. 38, Šiauliai LT-76352, Lietuva \\ E-pasts:kvasyte@hu.su.lt
}

\begin{abstract}
Latvijas lietuvieši dzimto valodu lieto galvenokārt ikdienas saziņā, tāpēc var būt sašaurinājušās šīs valodas funkcijas - plašāk izplatîts sarunvalodas paveids. Pētījumam izvēlēta lietuviešu runātā valoda, kas pierakstìta geogrāfiski Ziemeḷlietuvai tuvajos Latvijas rajonos, kā arī Rīgā. Dzīvojot svešas valodas vidē, ir grūti izvairīties no citvalodu ietekmes, šajā gadījumā lietuviešu dzimto valodu var ietekmēt latviešu valoda kā valsts iedzīvotāju pamatvaloda (valsts valoda). Citvalodu vidē dzīvojošu lietuviešu dzimtās valodas izmaiņas un tās specifika jau pētītas dažādos aspektos, visvairāk uzmanības veltīts fonētikai un leksikai. Šajā rakstā plašāk aplūkota darbības vārdu lietošana.

Latvijas lietuviešu sarunvalodā konstatēta darbības vārdu izvēles specifika. Atsevišķi gadījumi atklāj valodas vides ietekmi, piem., teikumos lietoti semantiski neiederīgi (citas nozīmes) darbības vārdi. Lietuviešu valodas darbības vārdi mēdz būt darināti ar latviešu valodai raksturīgiem vārddarināšanas līdzekḷiem, visbiežāk priedēkḷiem. Sastopami burtiski pārceltu lietuviskotu latviešu valodas darbības vārdu lietojumgadījumi. Izpētot darbības vārdu un to formu lietošanas specifiku, var apgalvot, ka atsevišķi no tiem ir samērā plaši izplatīti Latvijas lietuviešu dzimtajā valodā, citi gadījumi uzskatāmi par individuāliem (okazionāliem). Jāṇem vērā arī abu valodu izlokšņu loma.
\end{abstract}

Atslēgvārdi: lietuviešu valoda, sarunvaloda, Latvijas lietuvieši, dzimtā valoda, valodu kontakti, darbības vārdi.

\section{levads}

Lietuvieši iecel̦ojuši Latvijā dažādu iemeslu dēḷ. Padomju gados iemesli bija gan politiski (no izsūtījuma atgriezušies lietuvieši, kuriem nebija ļauts apmesties uz dz̄ivi dzimtenē, izvēēējās tai tuvāku dzīvesvietu), gan ekonomiski (meklēja labākus dzīves apstākḷus, tiecās pēc materiālās labklājības), gan personīgi (laulības ar latviešiem vai Latvijas iedzīvotājiem, norīkojums darbā, karadienests u.tml.). No Lietuvas pārcēlušies lietuvieši galvenokārt apmetās uz pastāvīgu dzīvi Latvijas galvaspilsētā un lielākajās pilsētās, kur bija vieglāk sameklēt darbu, īpaši rūpniecības uzṇēmumos, kā arī Lietuvas pierobežas pilsētu un lauku teritorijās (Treija, Dribins 1998; Jēkabsons 2003). Pierobežas apvidu izvēli noteica ǵeogrāfiskais tuvums dzimtenei un iespēja uzturēt sakarus ar tur palikušajiem tuviniekiem, īpaši, ja vin̄i bija cēlušies no robežai tuvu esošajām Lietuvas apdzīvotajām vietām. 
Dzimtā valoda ir viens no svarīgākajiem nacionālās pašapziņas rādītājiem, jo valoda ,tiek uztverta kā etniskās atšksirības pamatiezīme un etniska vērtība” (Arutjunjan et al. 1999, 153). Taču, dzīvojot ārpus savas zemes robežām, ir grūti izvairīties no svešās vides un valodas ietekmēm, tāpēc ir pamats runāt par valodu mijiedarbību. Latvijā dzīvojošo lietuviešu dzimtās valodas specifika pētīta dažādos aspektos, šajā rakstā galvenā uzmanība pievērsta vienai no vārdšksirām - darbības vārdam.

Pētījuma mērksis - izmantojot analītiski aprakstošo un sastatījuma metodi, analizēt darbības vārdu lietošanu Latvijas lietuviešu valodā. Pētījuma avoti ir divu Šauḷu pedagoǵiskā institūta (kopš 1997. gada Šauļu Universitāte) studentu ekspedīciju materiālu vākums samērā kompakti lietuviešu apdzīvotajās teritorijās Latvijas pierobežā: 1993. gadā Saldus rajona Rubā un 1995. gadā Dobeles rajona Bukaišos (sk. 1. attēlu), kā arī raksta autores personīgie Rīgā dzīvojošo lietuviešu runas pieraksti, kuri tiek pastāvīgi papildināti.

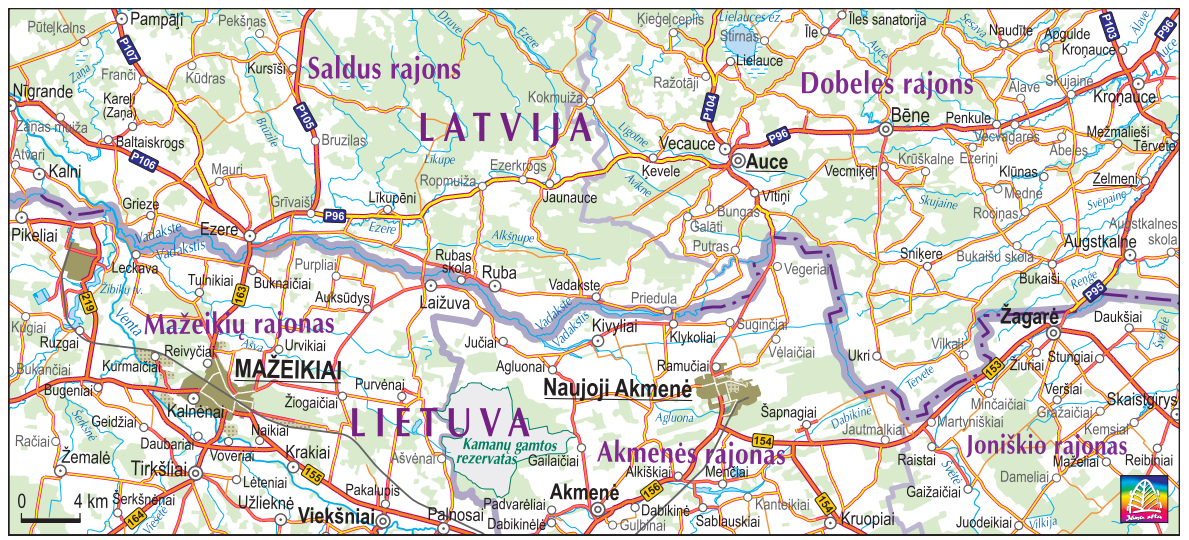

1. attēls. Lietuvas un Latvijas pierobeža (SIA ,Jāṇa sēta” karte).

\section{Latvijas lietuviešu valoda}

Līdz šim valodnieki biežāk ir pievērsušies Latvijā dzīvojošo lietuviešu izlokšṇu izpētei - galvenokārt analizēta fonētika un fonolog̣ija. Tas ir likumsakarīgi, jo, kā uzskata Kazimiers Garšva (Kazimieras Garšva), ,izlokšnu atšķirības visspilgtāk izpaužas fonētikā, valodu kontakti - arī leksikā, sintaksē" (Garšva 2005, 15) (par Latvijas lietuviešu izloksnēm sk. arī Garšva 2015). Salīdzinoši mazāk, tomēr ir pētīta arī Latvijas lietuviešu valodas leksika, morfoloğija un sintakse (plašāk par to sk. Kvašytė 2012).

Vērtējot Latvijas lietuviešu dzimtās valodas kvalitāti un tās lietošanas tendences, vispirms jāṇem vērā to lietuviešu, kuri iecel̦oja no Lietuvas, un to, kuri dzimuši Latvijā, valodas prasmes atšķirības. Lietuviešiem, kuri apmetās uz dzīvi Latvijā padomju laikposmā, nebija iespēju mācīties dzimto valodu skolā, jo tolaik Latvijā nebija ne lietuviešu mācībvalodas skolu, ne lietuviešu valodas stundu citās skolās. Latvijā brieduma gados ieradušies lietuvieši bija mācījušies Lietuvā, tāpēc viṇiem bija vismaz izglītības dzimtajā valodā pamati vai arī viṇi bija beiguši 
dažādu līmeṇu mācības lietuviešu valodā. Ne mazāk svarīgs faktors ir ǵimenes nacionālais sastāvs, kā arī katra cilvēka personīgais viedoklis par dzimto valodu un nepieciešamību to prast, tajā sazināties. Nav šaubu, ka lielu lomu spēlē tuvinieku un saziņas partneru skatījums uz cittautieti, uz citas valodas runātāju - kā viṇi vērtē tā dzimto valodu. Pētījumos konstatēts, ka lietuviešu valoda „Latvijā arvien vairāk kḷūst par mājas valodu. Tā jau līdz 1991. gadam bija attālinājusies no publiskās dzīves, jo nebija apstākḷu to plaši lietot" (Merkienè et al. 2005, 64).

Iespēja lietot dzimto valodu citvalodu vidē vairāk saistīta ar individuālās saziņas jomām. Turklāt cilvēki, kuri nav mācījušies skolā, nevar pilnvērtīgi prast literāro valodu. Viņu valodai vienmēr piemitīs sarunvalodas nokrāsa vai tajā būs izlokšņu iezīmes, jo mazākumtautības (pie tām pieskaitāmi arī lietuvieši, kuru skaits Latvijā gandrīz visa XX gadsimta garumā ir svārstījies no 1,2 līdz 1,5 procentiem) ${ }^{1}$ valoda neveic visas valodai raksturīgās sabiedriskās funkcijas. Literārā valoda ir jāmācās, bet sarunvaloda tiek nodota no vienas paaudzes nākamajai, un vairākas paaudzes var to saglabāt, pat nedzīvojot savas tautas valodas vidē. Viss teiktais attiecināms uz Latvijā dzīvojošo lietuviešu valodu: tā visbiežāk ir runas formā saglabāta ǵimenes viena vai abu vecāku - valoda. Savukārt iespēja lietot dzimto valodu citvalodu vidē pārsvarā saistīta ar individuālām un gímenes, neliela draugu loka vajadzībām (plašāka šî iespēja mēdz būt teritorijās, kur lietuvieši dzīvo kompakti).

Pašlaik notiek zināmas pārmaiṇas šajā jomā - pēc neatkarības atjaunošanas 1990. gadā dažādās Latvijas pilsētās (Rīgā, Jelgavā, Bauskā, Daugavpilī) izveidotas lietuviešu skolas, svētdienas skolas, nodibinātas lietuviešu biedrības, darbojas mākslas kolektīvi u. tml. (Treija, Dribins 1998; Budzinauskienè 2001; Merkienė et al. 2005), tāpēc lietuviešu valoda biežāk tiek lietota arī ārpus ǵimenes loka. Tomēr lietuviešu valodas situāciju nevar pielīdzināt latviešu valodai kā valsts iedzīvotāju pamatvalodai (valsts valodai) vai krievu valodai kā lielākās Latvijas minoritātes valodai. Tāpēc Latvijas lietuviešu starpā visvairāk izplatīta sarunvaloda resp. „literārās valodas paveids, ko lieto ikdienas sazin̄ā un kam raksturīgas specifiskas iezīmes, ko nosaka lietošanas sfēra .. Lielu ietekmi uz literāro sarunvalodu atstāj lietuviešu valodas izloksnes" (Ambrazas 2008, 624). Ne vienmēr ir iespējams nošķirt kontaktvalodas un izloksnes ietekmi, domājams, ka abas tās viena otru pastiprina. Izloksnes ietekme spilgtāka varētu būt šaurāka personu loka, piem., vienas ǵimenes vai no tās pašas vietas cēlušos lietuviešu runā, savukārt latviešu valodas ietekme spilgtāk izpaudīsies, ja būs izveidojušies ciešāki kontakti ar latviešiem.

\section{Darbības vārdu lietošana}

Latvijas lietuviešu valodas analīze liecina, ka darbības vārdu lietošanu var ietekmēt gan vispārlietojamai valodai raksturīgas retākas darbības vārdu nozīmes, gan lietuviešu valodas izloksnes (parasti dzimtā izloksne), gan latviešu valoda kā kontaktvaloda. Ikdienas saziņā darbības vārdi, tāpat kā citu vārdškşiru vārdi, specifiski savieno lietuviešu un latviešu valodas leksiski semantiskās un vārddarināšanas līdzības un atšksirības. Konstatēti arī gadījumi, kad darbības vārdi burtiski pārtulkoti no latviešu valodas vai tikai lietuviskotas to formas.

Pēc Pilsonības un migrācijas lietu pārvaldes 2015. gada 1. jūlija datiem, Latvijā dzīvo 27206 lietuvieši resp. 1,2 proc. (Iedzīvotāju reǵistrs) (sal. 1993. gadā 1,3 proc. (Kvašytė 2012, 42)). 
Leksiski semantiskā specifika vērojama gadījumos, kad pēc cilmes un formas līdzīgiem darbības vārdiem latviešu un lietuviešu valodā ir atšķirīgas nozīmes. Izvēlēties pēc formas tuvākus vai kopīgas cilmes vārdus Latvijas lietuviešus var rosināt latviešu valoda kā kontaktvaloda, reizēm izvēli ietekmē darbības vārdu semantika lietuviešu valodas izloksnēs. Tādējādi var runāt par plašāk izplatītām (kolektīvām) un okazionālām (individuālām) leksiski semantiskām atšķirībām.

Lietuviešu valodā darbības vārda sutikti nozīme 'sutarti, sugyventi' [satikt, sadzīvot ${ }^{2}$ fiksēta kā ceturtā no vienpadsmit šì vārda nozīmēm lietuviešu valodas vārdnīcā $(L K Z ̌ e s)^{3}$. Kā uzsvērts lietuviešu valodas gramatikā, tas ir viens no gadījumiem, kad atvasinātais darbības vārds izsaka jaunu jēdzienu, kuru grūti saistīt ar vārda, no kura tas atvasināts, nozīmi (Ambrazas 1994, 402). Salīdzinājumam var minēt, ka latviešu valodas atbilsme - darbības vārds satikt - atvasināts no indoeiropiešu cilmes darbības vārda, kura ,semantika izveidojusies no divām tikt nozīmēm: 1. no tikt ${ }^{\mathrm{a}}$ nozīmes 'derēt', no kā 'sadz̄ivot, saprasties' .. 2. no tikt ${ }^{\mathrm{b}}$ nozīmes 'kḷūt (pie kā)' $\rightarrow$ 'sastapt'..” (Karulis II, 403-404). Latvijas lietuviešu runā konstatēts lietojums, kas atbilst darbības vārda nozīmei mūsdienu latviešu valodā '.. 3. dzīvot, arī darboties, strādāt ciešā saistībā, labās attiecībās (ar kādu); sadzīvot' (Ceplītis, Stengrevica 7, 311) (sal. sinonīmus sadzīvot, arī saprasties (Rauhvargers 2002, 372)). Darbības vārdu satikt šajā nozīmē lietuviešu valodā tulko gan sugyventi, gan sutikti, gan sutarti (Butkus 2003, 649-650)5 ${ }^{5}$, taču Latvijas lietuviešu runā biežāk izplatīts ir tieši latviešu formai tuvākais darbības vārds:

(1) Su latves gal geriau sutikti nei su lietuves / sutarti, sugyventi6

'Ar latviešiem var labāk satikt nekā ar lietuviešiem' (Bukaiši)'.

(2) Aš visada norèjau gerai sutikti, bet marčia nenorejjo / sutarti, sugyventi

'Es vienmēr gribēju labi satikt, bet vedekla negribēja' (Rīga $)^{8}$.

Salīdzinot Latvijas lietuviešu runas pierakstus ar lietuviešu valodas pierobežas izlokšņu materiālu, kurš iekḷauts Ziemel̦lietuvas folkloras vācēja Mata Slančauska (Matas Slančiauskas) leksikas vārdnīcā, redzams, ka ar nozīmi 'sutarti' darbības vārds sutikti konstatēts arī izloksnēs (Švambarytė-Valužienè 2015, 600).

Latvijas lietuviešu sarunvalodā sastopams darbības vārds suimti. Viena no daudzajām š̄i darbības vārda nozīmēm vispārlietojamā lietuviešu leksikā ir 'gauti, sudaryti' [saṇemt, veidot] (LKŽe), kas latviešu valodas vārdnīcā fiksēta kā

2 Raksta vajadzībām tulkotie lietuviešu valodas vārdi, konstrukcijas vai citāti rakstīti kvadrātiekavās.

3 Leksikogrāfijas avota Lietuviu kalbos žodynas elektroniskās versijas saīsinājums LKŽe (literatūras sarakstā Naktinienè 2008).

4 Visu latviešu valodas vārdu nozīmes no Latviešu literārās valodas vārdnīcas, tāpēc tālāk tekstā tikai sējuma numurs un lappuse.

5 Tulkojot latviešu valodas vārdus lietuviešu valodā, izmantota vārdnīca Latvių-lietuviu kalbu žodynas (2003), tāpēc tālāk tekstā norādīta tikai lappuse.

6 Šeit un tālāk aiz slīpsvītras lietuviešu valodā vispārlietojamais darbības vārds citētajā teikumā iederīgā formā.

7 Pierakstīts Dobeles rajona Bukaišos (liet. Bukaišiai - tālāk saīsināti B).

8 Pierakstīts Rīgā (liet. Ryga - tālāk sāisināti Rg). 
darbības vārda saņemt trešā nozīme (pavisam to vārdnīcā ir deviņas) 'iegūt, dabūt savā īpašumā, lietošanā (parasti vienreizēju atalgojumu, apbalvojumu, dāvanu u. tml.); dabūt (piem., novērtējumu)' (7, 213-216). Iespējams, ka tieši latviešu valoda ietekmējusi respondentus izvēlēties lietuviešu darbības vārdu suimti, kaut gan tulkojošajā vārdnīcā kā tā ekvivalents šajā nozīmē minēts gauti (635):

(3) Daktarai tikrai dabar mažas algas suim / gauna

'Ārsti patiešām tagad mazas algas saņem' (Ruba)'.

(4) Buvo paštininké - suèmiau laiška iš brolio / gavau

'Bija pastniece - sañēmu vēstuli no brāḷa' (Rg).

Darbības vārds mainyti ar nozīmi 'keisti stambius pinigus smulkesniais arba vieną valiutą kita' [mainīt lielu naudu sīkākā vai vienu valūtu pret citu], kura kā pēdējā no sešām nozīmēm iekļauta lietuviešu valodas vārdnīcā (LKŽe), konstatēts Latvijas lietuviešu valodā. Savukārt mūsdienu latviešu valodā kā pirmā minēta kopcilmes darbības vārda mainīt (Karulis I, 559) nozīme 'dot (ko savu) un ņemt pretī (cita). Mainīt naudu - a. Mainīt naudas zīmi, monētu pret sīkākām, bet kopsummā līdzvērtīgām naudas zīmēm, monētām. b. Mainīt naudas zīmes, monētas pret citas valūtas naudas zīmēm, monētām ..' (5, 47-48). Lietuviešu valodā šo latviešu darbības vārdu tulko gan keisti, gan mainyti (383), taču tieši otro atbilsmi ir iecienījuši Latvijas lietuvieši ikdienas saziņā:

(5) Mainé [Latvijos rublius ị latus] du šimtus pret ${ }^{10}$ viena / keite

'Mainīja [Latvijas rubl̦us pret latiem] divus simtus pret vienu' (B).

(6) Ėjau išsimainyti pinigus, kitaip negalèsiu sumokèti [už autobuso bilietą] / išsikeisti

'Gāju izmainīt naudu, citādi nevarēšu samaksāt [par autobusa biḷeti]' (Rg).

Aplūkotajam lietojumam resp. nozīmei 'pakeisti stambius pinigus smulkesniais arba vieną valiutą kita' [apmainīt lielākas naudaszīmes pret sīkākām vai vienu valūtu pret citu] atbilst lietuviešu folkloras leksikas darbības vārda mainyti ligzdā iekḷautais atvasinājums apmainyti (Švambarytė-Valužienè 2015, 355-356), jo atvasinājums ar priedēkli parasti nosauc nevis jaunu jēdzienu, bet to pašu darbību, kas ieguvusi papildpazīmi (Ambrazas 1994, 402). Šajā gadījumā priedēklis uzsver procesa pabeigtību, taču semantiskas atškirības nerada.

Latvijas lietuviešu sarunvalodā konstatēts darbības vārds gulèti, lietots atbilstoši latviešu vārda gulèt nozīmei ‘būt aizmigušam' (3, 168-170). Arī lietuviešu valodā kā viena no perifērām ir fiksēta nozīme 'būti gulsčiam, būti išvirtusiam; ilsètis, miegoti' [būt gul̦us, būt izkritušam; atpūsties, gulēt] (LKŽe), taču biežāk š̄s nozīmes tiek diferencētas - izteiktas ar diviem atšķirīgiem darbības vārdiem. Pirmajā nozīmē lieto miegoti, tikai otrajā un trešajā - attiecīgi 'atrasties gulus stāvoklī (par cilvēkiem vai dz̄̄vniekiem)' un 'atrasties, būt novietotam (kur) - par priekšmetiem' (3, 168-170) - kopīgas cilmes (Karulis I, 323) darbības vārdu gulèti. Šo lietuviešu valodai raksturīgo nozīmju šķīrumu apliecina atbilsmes tulkojošajā

9 Pierakstīts Saldus rajona Rubā (liet. Ruba - tālāk saīsināti R).

10 Par šî u. c. prievārdu lietojumu Latvijas lietuviešu valodā plašāk sk. Kvašytè 2009. 
vārdn̄̄cā '1. miegoti; 2. gulèti (būti gulinčioje padètyje, būti kur padètam)' (224). Savukārt folkloras leksikas vārdnīcā fiksēts, ka gulèti pamatnozīme ir 'ilsètis būnant horizontalioje padètyje, gulint; nakvoti' [atpūsties, esot horizontālā stāvoklī, guḷus; nakšn,ot], taču latviešu valodas darbības vārdam tuvo nozīmi dal̦ēji atspoguḷo ar priedēkli atvasinātais darbības vārds išgulèti 'išmiegoti' (Švambarytè-Valužienè 2015, 234):

(7) Anie [jaunimas] dabar parein iš bales, kaip saka, iš vakaruškos un nuor lig pietu gulèt / miegot

'Viṇi [jaunieši] tagad pārnāk no balles, kā saka, no vakarēšanas un grib līidz pusdienām gulēt' (R).

(8) Ar gerai gulejai šiąnakt? / miegojai

'Vai labi gulēji šonakt?' (Rg).

Lietuviešu valodas darbības vārds spirti pēc cilmes saistīts ar latviešu spert, kura ,[P]amatā ide. *sp(h)er 'raustīt, spert, ķepuroties, mest' .. Sakne saistīta ar ide. *per- 'sit' ..' (Karulis II, 259). Minētais darbības vārds latviešu valodā izsaka pavisam septiņas nozīmes, taču kā pirmās vārdnīcā iekḷautas divas, kuras ir svarīgas, analizējot Latvijas lietuviešu valodas specifiku: '1. Ar strauju kājas kustību sist (cilvēkam vai dzīvniekam) uzbrūkot, aizsargājoties; ar strauju kājas kustību sist ( $p a$ ko), piem., lai (to) pārvietotu, sabojātu. 2. Elektriski izlādēties kādā vidē, priekšmetā u. tml. (par zibeni); izraisīties, zibenim elektriski izlādējoties (par pērkonu)' (7, 101-103). Lietuviešu valodā atbilstošo darbības vārdu tulko vai nu ar radniecīgo darbības vārdu spirti, vai darbības vārdu trenkti, ja izsaka pērkona darbību (684). Analog̣isks darbības vārds trenkt ir arī latviešu valodas vārdu krājumā, kur, kā norāda Konstantīns Karulis, tiek uzskatīts par apvidvārdu, precīzāk, „[P]ēc J. Endzelīna uzskata trenkt ir kursisms vai lituānisms ..” (Karulis II, 425). Kā liecina vārdnīcas dati, lietuviešu valodā piecpadsmitā no divdesmit astoņām darbības vārda spirti nozīmēm ir attiecināma uz pērkonu 'trenkti (apie griaustinị)' (LKŽe). Salīdzinājumam var minēt, ka izloksnēs konstatēta konstrukcija perkūnas spiria 'trenkia, griaudžia' [sper, grauj] (Švambarytè-Valužienè 2015, 528) resp. tā, kā konstatēts Latvijas lietuviešu runā:

(9) Viena karta vèl karves ganiau miške un ka spyré [žaibas] .. / trenkè

'Vienu reizi atkal govis ganīju mežā un kad spēra [zibens] ..' (B).

Darbības vārds užkloti, domājams, pēc latviešu valodas parauga lietuviešu sarunvalodā parādās konstrukcijā užkloti stalą resp. uzklāt galdu ar nozīmi 'uzlikt galda piederumus, arī ēdienus, dzērienus uz galda' $(8,134)$. Lai nosauktu galda klāšanas procesu, lietuviešu valodā parasti lieto darbības vārdu padengti, ja vien nav runa tikai par galdauta uzklāšanu. Šksiet, ka tieši pirmā no astoņām darbības vārda užkloti nozīmēm 'užtiesti, uždengti' (LKŽe) ir vistuvāk Latvijas lietuviešu runā konstatētajam darbības vārdam, tomēr nav pilnīgas pārliecības, ka šeit ir runa par ko vairāk nekā galdauta uzklāšanu uz galda:

(10) Ateis svečiai, reik skubèt stala užklot / padengti

'Atnāks ciemini, jāsteidzas galdu uzklāt' (R). 
Latvijas lietuviešu valodas materiālā konstatētā vārda išteriuoti vietā lietuviešu valodā parasti lieto išleisti, išeikvoti, sunaudoti, suvartoti (301). Neraugoties uz to, ka katram no darbības vārdiem piemīt zināmas nozīmes nianses, runājot par naudu, piemērotas ir lietuviešu valodas atbilsmes išleisti un išeikvoti (sal. latviešu valodas darbības vārda iztērēt nozīmes 'izdot (daudz vai visu, piem., naudu); nelietderīgi izdot' $(3,710))$. Šis darbības vārds ir raksturīgs arī Lietuvas lietuviešu sarunvalodai. Vārdnīcā fiksētā trešā no četrām nozīmēm 'sunaudoti, išleisti, išeikvoti' [izlietot, izdot, izšķēerdēt] (LKŽe) dal̦ēji aptver arī Latvijas lietuviešu lietojumgadījumu. Salīdzinājumam var minēt, ka Ziemeḷlietuvas folkloras leksikas vārdnīcā iekḷauts pierobežā fiksētais darbības vārds išterioti ar nozīmi 'nusiaubti, išniokoti' [izpostīt] (Švambarytė-Valužienė 2015, 595). Taču Latvijas lietuviešu sarunvalodā tas biežāk lietots tieši latviešu valodai raksturīgā nozīmē:

(11) Nuejjau i krautuvę ir išteriuojau visus pinigus / išleidau

'Aizgāju uz veikalu un iztērēju visu naudu' (R).

Latvijas lietuviešu valodai raksturīga darbības vārdu darināšanas specifika, saistīta galvenokārt ar priedēkļu izmantošanu. Tā kā ,viens un tas pats priedēklis, kombinējoties ar dažādiem motivētājvārdiem, spēj piešksirt tiem atšķirīgas nozīmes, savukārt dažādi priedēkḷi - vienādas" (Nītiņa, Grigorjevs 2013, 278), nav viegli diferencēt darbības vārdu nozīmes abās radniecīgajās valodās. Jāṇem vērā, ka priedēklis, saistoties ar pamatvārdu, ierobežo, kādā aspektā sašaurina, konkretizē pamatvārda nozīmi (Ambrazas 1994, 402). Tekstu analīze liecina, ka nereti Latvijas lietuvieši darina darbības vārdus atbilstoši latviešu valodas nozīmei, kaut lietuviešu valodā priedēkḷi vai nu vispār nav nepieciešami, vai konkrēto nozīmi izsaka citi priedēkḷi.

No viena un tā paša darbības vārda ar dažādiem priedēkḷiem var atvasināt atšksirīgu nozīmju darbības vārdus gan latviešu, gan lietuviešu valodā. Respondentu runā populārs ir darbības vārds gyventi - latviešu valodas dzīvot atbilsme - un tā atvasinājumi. Latviešu valodā ,,[B]lakus verba $d z \bar{\imath} v o t$ atvasinājumu ligzdai, kuru

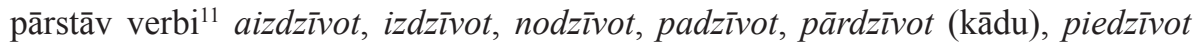
(pie kāda), sadzīvot (ilgi) veidojas nemotivēto verbu rinda ar individualizētām nozīmēm, t. i., apdzīvot (platību), iedzīvoties (mantā, vietā), pārdzīvot (notikušo), piedzīvot (pārsteigumu), sadzīvot (ar citiem), uzdzīvot" (Soida 2009, 230). Lai izteiktu darbības vārda iedzīvoties nozīmi '1. pierast un sākt justies labi, ērti (jaunā vietā, jaunos apstākḷos u.tml.)', lietuviešu valodā jāizvēlas semantiski precīzākais vārds no rindas issigyventi, isijausti, apsiprasti, priprasti, savukārt nozīmi 'kḷūt bagātam, turīgam, iegūt (materiālas vērtības)' (3, 251-252) - no rindas prasigyventi, praturtèti, ịsigyti (236). Lietuviešu darbības vārdu sastatījums liecina, ka atšķirīgas nozīmes darbības vārdam gyventi piešķir priedēkḷi $i$ - un pra-, taču refleksīvos atvasinājumus ịsigyventi un prasigyventi var uzskatīt par latviešu darbības vārda iedzīvoties ekvivalentiem. Runājot par dzīves apstākļu uzlabošanos un turības vairošanu, arī Latvijas lietuviešu valodā konstatēti ar aplūkotajiem priedēkḷiem atvasināti darbības vārdi. Taču grūti pateikt, vai runātājs izvēlējies pēc uzbūves latviešu valodas darbības vārdam tuvāku atvasinājumu, vai šādu lietojumu

11 Emīlija Soida monogrāfijā lieto termina darbības vārds sinonīmu verbs, kā arī termina priedēklis sinonīmu prefikss (Skujiņa 2007, 76; 309). 
balsta viņa izloksne vai retāk sastopamā vārda nozīme, kas iekḷauta lietuviešu valodas vārdnīcā (LKŽe):

(12) <..> pirms kara, nu po to pirmojo karo, tai jau ükininkai isigyveno, lauka buva čisti [nuo piktžoliu]] / prasigyveno

'.. pirms kara, nu pēc tā pirmā kara, tad saimnieki iedzīvojās, lauki bija tīri [no nezālēm]' (R).

Latvijas lietuviešu valodas materiālā konstatēts vēl viens darbības vārda gyventi atvasinājums, šoreiz ar priedēkli pri- - prigyventi. Pēc formas tas ir tuvs atvasinājumam ar priedēkli pie- resp. piedzīvot latviešu valodā. Lai izteiktu nozīmi 'kḷūt kāda notikuma līdzdalībniekam, kādas parādības vērotājam' $\left(6_{2}, 37\right)$, kas ir viena no piecām š̄ darbības vārda nozīmēm latviešu valodā, nereti Latvijas lietuvieši lieto darbības vārdu prigyventi (tieši nozīme 'patirti' ir fiksēta lietuviešu valodas vārdnīcā (LKŽe), kaut gan tāda atbilsme nav minēta tulkojošajā vārdnīcā (sal. '1. (ko) išgyventi, sulaukti (vecums); 2. išgyventi, patirti; 3. gyventi pas ką nors' (547)):

(13) Neduok dieve dar karta toki [karą] prigyventi / išgyventi, patirti

'Nedod Dievs vēlreiz tādu [karu] piedzīvot' (R).

Viena no nozīmēm, kādā latviešu valodā tiek lietots ar iepriekš minēto priedēkli pie- atvasinātais darbības vārds pienākt, ir 'iesākties, iestāties (par laikposmu)' $(6$, , 89-90). Lai šo darbības vārdu pārtulkotu lietuviešu valodā, piedāvātas atbilsmes '1. prieiti (prie ko; pilnam); 2. ateiti, užeiti' (554), taču Latvijas lietuvieši savā runā biežāk lieto priedēkḷa pri- atvasinājumu prieiti. Lietuviešu valodā starp divdesmit darbības vārda prieiti nozīmēm kā sestā vārdnīcā iekḷauta 'prislinkti, priartèti (apie laiką)' [pienākt, pietuvoties (par laiku)] (LKŽe), tāpēc grūti pateikt, vai šādu respondentu izvēli ietekmē kontaktvaloda vai tas, ka arī lietuviešu valodā attiecīgo nozīmi var izteikt ar šì priedēkḷa atvasinājumu, kaut arī vispārlietojamā leksikā priekšroka tiek dota citiem darbības vārdiem:

(14) Tokie laikai, dukrelès, priejo / atèjo

'Tādi laiki, meitiņas, pienāca' (B).

Latvijas lietuviešu valodai ir raksturīgs plašs ar priedēkli pri- atvasinātā darbības vārda prigimti lietojums. Kā latviešu valodas darbības vārda piedzimt pirmās nozīmes 'atdalīties no mātes organisma un sākt patstāvīgu eksistenci' $\left(6_{2}, 35\right)$ ekvivalenti lietuviešu valodā minēti gimti un užgimti (547). Taču priedēkḷa darbības vārds prigimti ar zināmu nozīmes niansi konstatēts gan lietuviešu valodas vārdnīcā 'gimti (ppr. ne pirmam vaikui šeimoje)' [dzimt (parasti ne pirmajam bērnam ğimenē)] (LKŽe), gan Ziemellietuvas teritorijā runātajā izloksnē 'susilaukti vaiko' [piedzimt bērnam] (Švambarytė-Valužienė 2015, 210). Tāpēc likumsakarīgi, ka respondenti lieto atvasinājumu ar priedēkli pri-:

(15) Mano vaikai čia [Latvijoje] prigimé, bet jie vis tiek lietuviai yr / gimè

'Mani bērni šeit [Latvijā] piedzima, taču viṇi vienalga lietuvieši ir' (B).

(16) Ar žinai, jai prigimè sūns / gimè

'Vai zini, viņai piedzima dēls' (Rg). 
Reizēm Latvijas lietuviešu valodā konstatēti darbības vārdu atvasinājumi ar priedēkḷiem, kuru lietojums atšķiras lietuviešu vispārlietojamā un izlokšņu leksikā. Latviešu valodā ierastā ar priedēkli sa- atvasinātā darbības vārda sasveicināties nozīmē 'sveicināt vienam otru, citam citu' $\left(7_{1}, 302\right)$ lietuviešu literārajā valodā biežāk lieto ar priedēkli $p a$ - atvasinātu tās pašas saknes darbības vārdu resp. pasisveikinti (648). Vārdn̄īās fiksētas izloksnēs lietotās konstrukcijas ar susisveikinti, piem., „Susitikom, susisvéikinom ir gražiai pasišnekèjom Gdl.” [Satikāmies, sasveicinājāmies un skaisti parunājāmies] (LKŽe), līdzīgi arī 'pasilabinti' [padot labas dienas] (Švambarytè-Valužienė 2015, 549) Ziemel̦lietuvas izloksnēs. Domājams, ka respondentu runu Latvijā ietekmējušas gan izloksnes, gan latviešu valoda:

(17) Latviai susisveikina taip pat kaip lietuviai / pasisveikina, sveikinasi

'Latvieši sasveicinās tāpat kā lietuvieši' (R).

(18) Mandagūs žmonès - visad susisveikina i kambari iẹję ... / pasisveikina, sveikinasi

'Pieklājīgi cilvēki - vienmēr sasveicinās, istabā ienākuši ..' (B).

Ar neatgriezeniskā darbības vārda sveikinti atvasinājumu apsveikinti (sal. latviešu atbilsmi apsveikt) lietuviešu vispārlietojamā valodā izsaka nozīmi 'iš eilès pasveikinti (ppr. paduodant ranką)' [pēc kārtas sasveicināties (parasti sniedzot roku)] (LKŽe). Neraugoties uz to, ka tāds darbības vārds lietuviešu valodā ir, ne tas, ne izlokšnuu dotumi neapstiprina, ka ši priedēkḷa atvasinājums būtu piemērots Latvijā pierakstītā teksta kontekstam (runa ir par kāzu tradīcijām). Darbības vārda apsveikt atbilsme lietuviešu valodā ir [pa]sveikinti (60):

(19) Atein mergelès draugai, apsveikin'ja / pasveikina

'Atnāk meitenes draugi, apsveic viņu' (R).

Vairāki ar priedēkli nu- atvasināti darbības vārdi - nulinkèti, nušvęsti, nušaukti - konstatēti Latvijas lietuviešu tekstos. Kā redzams, nereti š̄i priedēkḷa atvasinājumi izvēlēti, lai izteiktu ar priedēkli no- darinātu latviešu valodas darbības vārdu nozīmes, kaut gan lietuviešu valodā attiecīgo nozīmju izteikšanai lieto citus priedēkḷus. Piem., darbības vārds nušvęsti tiek lietots lietuviešu valodai raksturīgākā atvasinājuma atšvęsti (475) vietā (sal. latviešu nosvinēt 'svinēt un pabeigt svinēt' $(5,706))$, bet nulinkèti - atvasinājuma palinkèti vietā (sal. latviešu novēlēt '1. Izteikt vēlējumu; vēlēties, lai (kas) būtu, realizētos ..' $(5,741))$ :

(20) Pas tą dukra nušventè, tada nuvažiava pas vyrą / atšventè

'Pie tās meitas nosvinēja, pēc tam brauca pie vīra' (R).

(21) Latvis jau lietuviui dažnai nenulinkès gero / ne[pa]linkès

'Latvietis jau lietuvietim bieži ne[no]vēlēs labu' (R).

Latvijas lietuvieši samērā bieži lieto darbības vārdu nušaukti, kura divpadsmitā no trīspadsmit nozīmēm lietuviešu valodā ir 'pavadinti' (LKŽe). Iespējams, ka šādu izvēli ir ietekmējušas daudznozīmīgā latviešu valodas darbības vārda nosaukt nozīmes '1. Piešksirt vārdu, nosaukumu. 2. Pateikt (kā) vārdu, apzīmējumu. 3. Saucot pateikt. 4. Saucot, ar saucienu panākt, ka (kāds) virzās un pabeidz 
virzīties lejā, nost' (5, 657-658), kuru izteikšanai lietuviešu valodā lieto atšķirīgus darbības vārdus, piem., pavadinti, duoti varda, praminti (469), lai izteiktu pirmo nozīmi, išvardyti - otro, vēl pasiūlyti, iškelti u. tml. (469-470). Minētajos teikumos vislabāk derētu atbilsme išvardyti, taču nereti Latvijas lietuvieši izvēlas latviešu valodai tuvo darbības vārdu:

(22) Nenušaukè per televizoriu, kas pabringo Lietuvo / neišvardijo

'Nenosauca pa televizoru, kas kḷuva dārgāks Lietuvā' (Rg).

(23) Viršininkai gali nušaukti, kur dirbt, ir reiks eit... / išvardyti, pasakyti

'Priekšnieki var nosaukt, kur strādāt, un būs jāiet...' (B).

Nereti Latvijas lietuviešu valodā lietoti burtiski pārcelti latviešu valodas darbības vārdi. Tie ir gadījumi, kad lietuviešu valodā, pat ja tajā ir līdzīgs vārds, tam nepiemīt nozīme, kādā šis darbības vārds (bieži vien atvasinājums) lietots respondentu runā.

Latvijas lietuviešu valodas pierakstos konstatēts darbības vārds parskelt. Tas ir latviešu valodas darbības vārda pārškselt resp. 'šķel̦ot pārdalīt; šķ̧ęlot radīt (kam) caurumu, bojājumu’ $\left(6_{1}, 413\right)$ lietojums. Acīmredzams, ka notikusi kopīgas cilmes darbības vārdu - lietuviešu skelti un latviešu šķelt (Karulis II, 347) kontaminēšanās resp. ,[V]alodas vienības (parasti vārda vai izteiciena) formas vai nozīmes pārveidošanās, ko izraisījusi formu, funkciju vai asociāciju tuvība un mijiedarbība ar citu ši paša līmeņa valodas vienību ..” (Skujiņa 2007, 192). Lietuviskots tikai pēc formas - parškelt - un pielāgots lietuviešu gramatikas normām (lietots atbilstošās personas, dzimtes un laika formā), kaut gan lietuviešu valodā attiecīgā darbības vārda atbilsmes ir gan līdzīgs pašvalodas darbības vārds perskelti, t. y. 'skeliant perdalyti' [šķel̦ot sadalīt] (LKŽe), gan suskaldyti; perkirsti; perskrosti (524):

(24) Viena karta vèl karves ganiau miške un ka spyré $\dot{e}^{12}$ [žaibas] un par pusị egles parškèlè: tada bais' išsigandau... / perskèlè

'Vienu reizi atkal govis ganīju mežā un kad spēra [zibens] un uz pusēm egles pāršksēla: tad l̦oti nobijos ..' (R).

L̄̄̇zīgi ir noticis ar darb̄̄bas vārdu prikristi, kuršs, tiesa, noliegumā neprikristi, lietots kā latviešu valodā darbības vārds piekrist ar nozīmi 'atzīstot par pareizu, pievienoties (iepriekš teiktajam)' $\left(6_{2}, 60\right)$. Kā šì darbības vārda atbilsmi lietuviešu valodā parasts lietot nepritarti, nesutikti [nepiekrist] (441). Kaut gan pēc formas analoǵisks darbības vārds iekḷauts gan lietuviešu valodas vārdnīcā (LKŽe), gan pierobežas folkloras leksikas vārdnīcā (Švambarytè-Valužienè 2015, 313), tā nozīmes neatbilst Latvijas lietuviešu sarunvalodā fiksētajam lietojumam (jāpiebilst, ka arī šì teikuma konstrukcija nav raksturīga lietuviešu valodai - par Latvijas lietuviešu valodas prievārdu konstrukcijām plašāk sk. Kvašyte 2009):

(25) Aš prie to irgi neprikrintu / su tuo nesutinku

'Es arī tam nepiekrītu' (B).

12 Par šĩ darbības vārda lietošanu sk. iepriekš. 
Respondenta runas pierakstā kā okazionāls darinājums konstatēts latviešu valodas darbības vārda plātīties tā pirmajā nozīmē 'plaši kustināt rokas, parasti pastiprinot izteikuma saturu' $\left(6_{2}, 254\right)$ lietuviskojums platitis. Jāpiebilst, ka tas nebūs saprotams lietuviešiem, kuri neprot latviešu valodu, jo šim darbības vārdam lietuviešu valodā atbilst izteiciens sketrioti rankomis (569):

(26) Ani [kunigai] seniau tik prie altoriaus platijos / sketriojo rankomis

'Viṇi [mācītāji] agrāk tikai pie altāra plātījās' (B).

\section{Secinājumi}

Citvalodu vidē pastāvīgi dzīvojošiem cilvēkiem arvien nākas apzināti izvēlēties saziņas valodu, ja viņi prot vairāk nekā vienu - dzimto - valodu. Latvijas lietuvieši dzimto valodu lieto galvenokārt ikdienas saziņā, tāpēc ir sašaurinājušās šīs valodas funkcijas. Plašāk izplatīts sarunvalodas paveids, turklāt, dzīvojot svešas valodas vidē, ir grūti izvairīties no citvalodu ietekmes. Latvijas lietuviešu sarunvalodā konstatēts specifisks darbības vārdu lietojums. Analizējot Latvijas lietuviešu darbības vārdu, to formu un atvasinājumu lietošanu, atsevišķi gadījumi atklāj valodas vides ietekmi, piem., teikumos lietoti semantiski neiederīgi (citas nozīmes) darbības vārdi. Lietuviešu valodas darbības vārdi mēdz būt darināti ar latviešu valodai raksturīgiem vārddarināšanas līdzekḷiem, visbiežāk priedēkḷiem. Sastopami burtiski pārceltu lietuviskotu latviešu valodas darbības vārdu lietojumgadījumi. Jāṇem vērā arī abu valodu izlokšņu loma. Pētot darbības vārdu un to formu lietošanas specifiku, var apgalvot, ka atsevišksi no tiem ir samērā plaši izplatīti Latvijas lietuviešu dzimtajā valodā, citi gadījumi uzskatāmi par individuāliem (okazionāliem).

\section{Literatūra}

1. Ambrazas, Vytautas (red.). 1994. Dabartines lietuviu kalbos gramatika. Vilnius: Mokslo enciklopedijų leidykla.

2. Ambrazas, Vytautas (red.). 2008. Lietuviu kalbos enciklopedija. Parengė Kazys Morkūnas. Vilnius: Mokslo ir enciklopedijų leidybos institutas.

3. Arutjunjan, Jurik et al. 1999. Etnosociologija. Moskva: Aspekt Press.

4. Budzinauskienè, Jovita. 2001. Latvijos lietuviu bendruomene. Vilnius: Voruta.

5. Butkus, Alvydas (red.). 2003. Latviu-lietuviu kalbu žodynas. Kaunas: Aesti.

6. Ceplītis, Laimdots, Stengrevica, Melita (red.). 1972-1996. Latviešu literārās valodas vārdnīca. Rīga: Zinātne.

7. Garšva, Kazimieras. 2005. Lietuviu kalbos paribio šnektos (fonologija). Vilnius: Lietuvių kalbos institutas.

8. Garšva, Kazimieras. 2015. Latvijos lietuviu šnektos. Vilnius: Lietuvių kalbos institutas.

9. Iedzīvotāju registrs. Pieejams: http://www.pmlp.gov.lv/sakums/statistika/ iedzivotaju-registrs/

10. Jēkabsons, Ēriks. 2003. Latvijas lietuvieši. Rīga: Elpa.

11. Karulis, Konstantīns. 1992. Latviešu etimoloğijas vārdnīca. 2 sēj. Rīga: Avots. 
12. Kvašytė, Regina. 2009. Besonderheiten der Umgangssprache der Litauer Lettlands: Gebrauch der Präpositionen. Dialectologia et Geolinguistica. 17/1, 38-51.

13. Kvašytė, Regina. 2012. Tarp Lietuvos ir Latvijos: lingvistinès paralelès. Starp Lietuvu un Latviju: lingvistiskās paralēles. Šiauliai: VšI Šiaulių universiteto leidykla.

14. Merkienè, Irena Regina et al. 2005. Pietryčių Latvijos lietuviai: tapatumo išraiška, etninès ir kultürinés orientacijos. Vilnius: Versus aureus.

15. Naktinienè, Gertrūda (red.). 2008. Lietuviu kalbos žodynas. (I-XX, 1941-2002): elektroninis variantas (LKŽe). Vilnius: Lietuvių kalbos institutas. Pieejams: www. $1 \mathrm{kz} .1 \mathrm{t}$

16. Nītiņa, Daina, Grigorjevs, Juris (red.). 2013. Latviešu valodas gramatika. Rīga: LU Latviešu valodas institūts.

17. Rauhvargers, Eižens (red.). 2002. Sinonīmu vārdnīca. 3. papild. un pārstr. izd. Rīga: Avots.

18. Soida, Emīlija. 2009. Vārddarināšana. Rīga: LU Akadēmiskais apgāds.

19. Švambarytė-Valužienè, Janina. 2015. Mato Slančiausko ir jo pagalbininku pasakojamosios tautosakos rinkinių leksika. Žodynas. Vilnius: Lietuvių kalbos institutas.

20. Treija, Aldona, Dribins, Leo. 1998. Lietuvieši. Mazākumtautību vēsture Latvijā. Rīga: Zvaigzne ABC, 43-61.

\section{Summary}

Lithuanians living in Latvia usually use their mother tongue in daily communication; therefore, the functions of this language have become narrower. Mostly, a variety of spoken language is attributed to a common feature of a freer use and neglect of linguistic requirements. Living in a foreign linguistic environment, it is difficult to avoid the impact of other languages; therefore, in the present case Lithuanian as a native language can be impacted by Latvian as a dominating language of state residents. Changes in the native language observed in a foreign language environment have already been investigated in various aspects, usually at the levels of phonetics and lexis. The presentation will investigate the use of one of the parts of speech, verb, in greater detail.

In the spoken Lithuanian of Latvian Lithuanians we noticed certain specificity regarding choosing verbs. Some cases reveal the impact of the linguistic environment, for instance, semantically incorrect (of the other meaning) verbs are used in sentences. The verbs of Lithuanian include elements of composition characteristic to Latvian, usually prefixes. Quite often, the cases of literally translated Latvian verbs are observed. Verbal constructions following an example of Latvian are used. Also, Lithuanian of Latvian Lithuanians, just like the spoken Lithuanian of Lithuanians living in Lithuania characteristically contains abundance of vernacularisms, loan-translations or barbarisms. A clear feature of spoken language is the shortening of endings in sentences.

The investigated choice of verbs and the use of their forms prove that some verbs or their forms are broadly spread in the spoken Lithuanian of Latvian Lithuanians; other cases ought to be treated as individual (occasional). 